\title{
Effect of some Postharvest Treatments on Quality of "Alphonse" Mango Fruits during Cold Storage
}

\author{
Abd El-Gawad M.G., Zeinab A. Zaki and Z. A. Ekbal \\ Fruit Handling Res. Dept., Hort. Res. Instit., Agric. Res. Center, Giza, Egypt
} Received: 11 August 2019/Accepted 10 Oct. 2019 / Publication date: 25 Oct. 2019

\begin{abstract}
The effect of different treatments; chitosan, gum Arabic and Aloe vera gel addition to control on fruit quality of mango (Mangifera indica, L. cv. Alphonse), in 2017 and 2018 seasons during storage periods at low temperature $13 \pm 1{ }^{\circ} \mathrm{Cand}$ air (90-95\% relative humidity) for 30 days was investigated. The quality characteristics such as fruit weight loss, disorders, firmness, TSS, titratable acidity, vitamin $\mathrm{C}$ and total sugars were determined at an interval of 10 days during storage. Results showed that, in both seasons, all used treatments caused a significant decrease in fruit weight loss and disorders percentage during cold storage as compared with control. Where, it was increased significantly with prolonging storage periods compared with initial date. Furthermore, the pervious treatments significantly increased fruit firmness, total soluble solid, total sugars and vitamin $\mathrm{C}$, where it were caused a significantly decrease in titratable acidityduring cold storage period in compared with control. At the end of storage periods, the lowest values of fruit weight loss were presented by gum Arabic $10 \%$ and fruit disorders was presented by chitosan 2\% and gum Arabic 10\%. Where, chitosan $2 \%$, gum Arabic $10 \%$ and Aloe Vera gel $50 \%$, positively, affected postharvest quality prosperities including fruit firmness, TSS, titratable acidity, ascorbic acid and total sugars in comparison with other treatments
\end{abstract}

Keywords: "Alphonse" mango, chitosan, Aloe Vera, gum Arabic, quality and storability

\section{Introduction}

Mango (Mangifera indica L.) is a tropical climacteric fruit and ripens very fast in harsh climatic conditions. Best quality is retained at the lowest possible storage temperature tolerated by the product. Postharvest diseases and short shelf life are the major problems of mango fruit, which affecting its quality (Zheng et al., 2012). Various biochemical changes during the ripening process affect fruit composition and quality.

Several techniques have been used to reduce deterioration, extend the shelf life and maintain quality of mango fruit, including low temperature and coatings (Ravindra and Goswami, 2007).Natural products are useful and taking place as an alternative approaches for delaying ripening and reducing postharvest deterioration of fruit (Tripathi and Dubey, 2004). Among the compounds used for this purpose is chitosan, a high molecular weight cationic polysaccharide derived from chitin (Zhong and Xia, 2007) that happens to be nontoxic, biocompatible and biodegradable (Shigemasa et al., 1994), and was reported to delay ripening of mango fruits up to 9 days (Srinivasa et al., 2002). Chitosan, also is a natural biopolymer containing $(1,4)$-linked 2 -amino-deoxy- $\beta$-d-glucan, derived by deacetylation of chitin as reported by Aider (2010). It has a wide range of uses in fruit and vegetable, because of its film forming, biochemical properties and antimicrobial activity (Devlieghere et al., 2004).

Gum Arabic is a polysaccharide natural secretion from Acacia species and used in industries for film forming, emulsification, and encapsulation properties. Gum Arabic Aloe vera gel appears to contain various antibiotic and antifungal compounds that can potentially delay or inhibit microorganisms that are responsible for food borne illness in humans as well as food spoilage. Recently, the use of Aloe vera gel as an edible surface coating has been reported to prolong the shelf life and to delay the changes in the parameters related to deterioration of quality in sweet cherry and table grapes (Martinez-Romero et al., 2006; Serrano et al., 2006). In the other hand, Aloe Vera gelbased edible coatings prevent loss of moisture and firmness, control respiratory rate, delay oxidative browning and reduce microorganism proliferation in fruits (Castillo et al., 2010).

Corresponding Author: Abd El-Gawad M.G., Fruit Handling Res. Dept., Hort. Res. Inst., Agric. Res. Center, Giza, Egypt. E-mail: m_gomaa_2010@yahoo.com 
Temperature, on the other hand, is an important component that affects quality of mango. Low temperature storage has been used in the enhancement of shelf life and quality maintenance in various fruits. The extension of storage life under cool temperature is due to the reduction in respiration rate and lowering the production of ethylene. However, due to its tropical origin, mango is susceptible to chilling injury at lower temperatures. Storing mango at $13^{\circ} \mathrm{C}$ has been demonstrated to extend the postharvest life of mangoes. However, temperature below $10^{\circ} \mathrm{C}$ causes chilling injury and above $15^{\circ} \mathrm{C}$ leads to shorter postharvest storage life (Ezz and Awad, 2011).

Therefore, the main target of our study was to study the effect of chitosan, gum Arabic and Aloe Vera gel as postharvest treatments on quality of mango (Mangifera indica L. cv. Alphonse) fruits during cold storage periods at $13 \pm 1^{\circ} \mathrm{Cin}$ air $(90-95 \%$ relative humidity).

\section{Materials and Methods}

\section{Plant materials}

Mature and hard green mango (Mangifera indica L. cv. Alphonse) fruit were obtained from a private orchard at El-Nubaria region, El-Behira governorate, Egypt. After harvest fruits were transported quickly to the laboratory within a day. Only the firm and well developed fruits of uniform size and maturity, free from pest, disease, injuries, bruises and blemishes were selected for the experiment with three materials; gum Arabic, chitosan and Aloe vera gel.

\section{Preparation of dipping solutions}

Leaves of Aloe Vera harvested from a private orchard at El-Nubaria region, El-Behira governorate, Egypt. Only the fully extended mature leaves were harvested, then stored in plastic papers and transported to the laboratory within same day. Aloe gel was obtained from fresh aloe leaves, the matrix was separated from the outer cortex of the leaves and the colourless hydroparenchyma homogenized in a blender. The resulting mixture was filtered using Watman filter paper number 100 to remove the fibres. The liquid constituted fresh Aloe vera gel. The gel matrix was pasteurized at $70^{\circ} \mathrm{C}$ for $45 \mathrm{~min}$. For stabilizing, the gel was cooled immediately to an ambient temperature and $4.5 \mathrm{~g}$ of ascorbic acid was added; $4.5 \mathrm{~g}$ of citric acid was then added to adjust the $\mathrm{pH}$ to 4 .

Gum Arabic solution 5 and $10 \%(\mathrm{w} / \mathrm{v})$ was prepared by dissolving 5 and $10 \mathrm{~g}$ of gum Arabic powder in $100 \mathrm{~mL}$ distilled water. The solution was heated at $40^{\circ} \mathrm{C}$ for $60 \mathrm{~min}$, using a hot plate magnetic stirrer (Model SP 18420-26 Barnstead thermolyne 2555 Kerper Boulevard Dubuque, USA). Glycerol $1.0 \%$ was also added as a plasticizer to the coating solutions. The $\mathrm{pH}$ of the solution was adjusted to 5.6 with $1 \mathrm{~mol} \mathrm{~L}^{-1}$ sodium hydroxide $(\mathrm{NaOH})$ using a $\mathrm{pH}$ meter (GLP 21, Crison, Barcelona).

Chitosan coating solution 1 and $2 \%(\mathrm{w} / \mathrm{v})$ was prepared by dissolving 1 and $2 \mathrm{~g}$ of chitosan in $100 \mathrm{~mL}$ distilled water containing $1 \%(\mathrm{v} / \mathrm{v})$ glacial acetic acid. The solution was agitated constantly using a magnetic stirrer for $3 \mathrm{~h}$. The suspension was filtered through cheese cloth in order to eliminate the insoluble material. The $\mathrm{pH}$ of the solution was adjusted to 5.6 with $1 \mathrm{~mol} \mathrm{~L}^{-1} \mathrm{NaOH}$, and $0.2 \mathrm{~mL}$ of Tween-20 also added to improve wettability. Treatments for the experiment were: (1) only water as a control, (2) chitosan 1\%, (3) chitosan 2\%, (4) gum Arabic5\%, (5) gum Arabic 10\%, (6) Aloe Vera gel 25\% and (7) Aloe Vera gel 50\%.

Fruits were washed with $0.01 \%$ sodium hypochlorite for $2 \mathrm{~min}$, and dried in air at ambient temperature. The mangos fruit were randomly divided into seven groups of 60 fruits each. All the treatments were conducted with three treatments. One of the seven dipping treatments was then applied to each group. The first group was dipped in water as a control. The other three groups were dipped in the corresponding solutions for three minutes. After dipping, fruits were air-dried for one hour. All fruits were packed in plastic boxes $(40 \times 30 \times 12 \mathrm{~cm})$, and then the fruits were stored at $13 \pm 1^{\circ} \mathrm{Cin}$ air (90-95\% relative humidity) for 30 days. The data were collected before treatment (day 0 ) and at 10 day intervals for 30 days during cold storage. Fifteen fruits of each treatment were sampled at each interval.

Fruit weight loss (\%): Was measured by the difference between the initial and final weight of each replication. It was expressed as a percent (\%) using the following equation: 


$$
\text { Weight loss } \%=\frac{\text { (Initial weight of fruits }- \text { Weight of fruits at inspection date) }}{\text { Initial weight of fruits }} \times 100
$$

Fruit firmness $\left(\boldsymbol{l b} / \mathbf{i n c h}^{2}\right)$ : Was measured using a Magness-Taylor penetrometer (pressure tester). Readings were taken in two positions in each tested fruit, averaged and recorded in lb/inch ${ }^{2}$.

Fruit disorders (\%):

The percentage of disordered fruits included all of the spoiled fruits resulted from rots, fungus, bacterial and pathogens were assessed and the defects were calculated as follows:

$$
\text { Disorders } \%=\frac{\text { No. of fruit disorders }}{\text { No. of fruit at the beginning of storage }} \times 100
$$

Total soluble solids (TSS \%): Fruit TSSpercentage were determined by a hand refractometer according to (A.O.A.C., 1994).

Titratable acidity (TA\%): To determine the titratable acidity of the fruit, $10 \mathrm{~g}$ of pulp of each fruit were first diluted with sterile distilled water to achieve $50 \mathrm{ml} .10 \mathrm{ml}$ of the dilution were then titrated with $0.1 \mathrm{~N} \mathrm{NaOH}$ according to the process reported by the A.O.A.C. (1999). The results were expressed as a percentage of citric acid present in the samples ( $\mathrm{g}$ citric acid/ $100 \mathrm{~g}$ fresh pulp weight).

Total sugars (g. glucose per 100 g. fresh weight): Were determined colorimetrically using phenol and sulphuric acid according to Malik and Singh (1980) and the concentration was calculated as $g$ glucose per $100 \mathrm{~g}$. fresh weight.

Vitamin C (mg ascorbic acid per $100 \mathrm{ml}$ juice): Vitamin $\mathrm{C}$ content was determined in fruit juice using 2, 6-dichlorophenol-indo-phenol blue dye as $\mathrm{mg}$ ascorbic acid per $100 \mathrm{ml}$ juice (A.O.A.C., 1980).

Experimental design and statistical analysis: Data of the present study were subjected to the analysis of variance test (ANOVA) as a factorial experiment in a Randomized Complete Block Design (RCBD). Where the first factor was for seven treatments mentioned before, the second factor was for storage period. The least significant differences (LSD) at the 5\% level of probability were calculated using a computer program SAS according to Gomez and Gomez (1984).

\section{Results and Discussion}

\section{Fruit weight loss}

Data of studying the effect of chitosan, gum Arabic and Aloe Vera gel postharvest treatments during cold storage on weight loss of mango (Mangifera indica L. cv. Alphonse) in 2017 and 2018 seasons was reported in Table (1). Data showed that weight loss percentage increased with increasing storage periods, and the differences among all tested storage periods were statistically significant compared with the initial date in both seasons of study.

Furthermore, chitosan, gum Arabic and Aloe vera gel treatments significantly decreased fruit weight loss percentage compared with control in 2017 and 2018 seasons. In addition, the treatments of gum Arabic at $10 \%$ were more effective and significant on decreasing fruit weight loss during cold storage compared with other treatments. The loss of fresh fruits and vegetables weight is mainly due to the loss of water caused by transpiration and respiration processes (Wang et al., 2007; Zhu et al., 2008 and Elsabee and Abdou, 2013). The increase of mango fruit weight loss during storage may be due to the increase of the respiratory metabolism of the fruits and exacerbate the loss of water absorbed by the chitosan coating on the fruit surface (Zhu et al., 2008 and Abbasi et al., 2009). Chitosan coating forms a layer of semi-transparent to smooth the pericarp surface (González-Aguilar et al., 2009) and can be used as a protective barrier to reduce respiration and transpiration rates through fruit surfaces (Wang et al., 2007; Zhu et al., 2008 and Elsabee \& Abdou, 2013).Chitosan coating treatment of mango fruits was clearly effective in conferring a physical barrier to moisture loss, therefore a decreasing of weight loss in coated fruit with chitosan was observed in this study. 
Moreover, the loss of water from treated fruits was lesser than the control. This was due to the fact that Aloe vera coating served as semi permeable membrane around fruit surface.

In a previous study was conducted to find out the effects of Aloe vera gel and chitosan on postharvest quality of mango fruit cv. Chok Anan. It was found that, at $25^{\circ} \mathrm{C}$ storage temperature, fruit coated with $1 \%$ chitosan and $20 \%$ Aloe vera gel could delay fruit weight loss changes of coated fruit than the other treatments (Mongkon Intalook, 2005).Nongtaodum and Jangchud (2009) also, reported that chitosan can retard weight loss of fresh cut mango significantly. Figueroa et al. (2011) noted that such effect may be due to less structure destabilization of cuticle cells caused by chitosan treatment.

Table. 1: Effect of chitosan, gum Arabic and Aloe vera gel postharvest treatments on weight loss percentage of "Alphonse" mango fruits during cold storage at $\left(13 \pm 1^{\circ} \mathrm{C}\right.$ and $90-95 \%$ R.H.) in 2017 and 2018 seasons.

\begin{tabular}{|c|c|c|c|c|c|}
\hline \multirow{3}{*}{ A-Treatments } & \multicolumn{5}{|c|}{ B- Storage Periods (Days) } \\
\hline & $\mathbf{0}$ & 10 & 20 & 30 & Means (A) \\
\hline & \multicolumn{5}{|c|}{ Season 2017} \\
\hline Control & 0.000 & 3.928 & 7.954 & 13.386 & 6.317 \\
\hline Chitosan (1\%) & 0.000 & 2.807 & 5.787 & 9.622 & 4.304 \\
\hline Chitosan (2\%) & 0.000 & 2.454 & 5.498 & 8.031 & 3.995 \\
\hline Gum Arabic (5\%) & 0.000 & 2.639 & 5.155 & 7.963 & 3.939 \\
\hline Gum Arabic (10\%) & 0.000 & 2.229 & 4.768 & 7.208 & 3.551 \\
\hline Aloe vera Gel (25\%) & 0.000 & 3.148 & 5.918 & 8.852 & 4.479 \\
\hline Aloe vera Gel (50\%) & 0.000 & 2.551 & 5.595 & 8.297 & 4.111 \\
\hline Means (B) & 0.000 & 2.822 & 5.811 & 8.908 & \\
\hline \multirow[t]{2}{*}{ LSD $_{\text {at } 0.05}$} & \multicolumn{5}{|c|}{ Treatments (A): 0.265 Storage Periods $(B): 0.201$ Interaction $(A \times B): 0.529$} \\
\hline & \multicolumn{5}{|c|}{ Season 2018} \\
\hline Control & 0.000 & 4.142 & 8.181 & 14.135 & 6.614 \\
\hline Chitosan (1\%) & 0.000 & 3.065 & 6.188 & 8.887 & 4.535 \\
\hline Chitosan $(2 \%)$ & 0.000 & 2.856 & 5.795 & 8.199 & 4.212 \\
\hline Gum Arabic (5\%) & 0.000 & 2.725 & 5.509 & 8.257 & 4.123 \\
\hline Gum Arabic (10\%) & 0.000 & 2.437 & 4.952 & 7.322 & 3.678 \\
\hline Aloe vera Gel $(25 \%)$ & 0.000 & 3.274 & 6.533 & 9.200 & 4.752 \\
\hline Aloe vera Gel (50\%) & 0.000 & 3.088 & 6.042 & 8.417 & 4.387 \\
\hline Means (B) & 0.000 & 3.084 & 6.171 & 9.203 & \\
\hline
\end{tabular}

\section{Fruit disorders}

Results of the present investigation, presented in Table (2) showed the effect of chitosan, gum Arabic and Aloe vera gel postharvest treatments during cold storage on disorders percentages of mango (Mangifera indica L. cv. Alphonse) in 2017 and 2018 seasons. Data showed that fruit disorders increased with increasing storage periods, and the differences among all tested storage periods were statistically significant compared with the initial date in the two seasons of study. Moreover, chitosan, gum Arabic and Aloe vera gel significantly decreased fruit disorders percentage compared with control.

Data also, revealed that chitosan treatments were more effective on decreasing fruit disorders than other treatments in two seasons of study. In addition, chitosan at 2\% and gum Arabic at $10 \%$ in two seasons and Aloe vera gel at 50\% in second season were caused a significant decreased on fruit disorders compared with other treatments.

Mango fruits susceptibility to postharvest diseases during storage as a result of the physiological changes and senescence process (Prusky \& Keen, 1993). The reduction of mangoes decay incidence during storage because of pre-harvest applications of chitosan, gum Arabic and Aloe vera gel treatments may be due to the low respiration rate and the delay of senescence, which could enhance resistance to infection and lesion development as has been previously suggested by Zeng et al. (2010) and Wang et al. (2014). Chitosan inhibits the growth of decay and induces defense response in host tissues (Shibuya \& Minami, 2001 and Zeng et al., 2010). Chitosan treatment showed positive effects in maintaining membrane integrity and increasing the activities of antioxidant enzymes and 
phenolic compounds (Jiang \& Li, 2001; Zeng et al., 2010; Hong et al., 2012 and Kumari et al., 2015). Moreover, The $\mathrm{NH}_{3}+$ group of chitosan may also restrain the propagation of harmful germs and promoting protection from further fungal, thus effectively controlled fruit decay (Devlieghere et al., 2004). In this regard, Wang et al. (2007) and Zhu et al. (2008) reported that pathogenic microorganisms were diminished when mango fruits were coated with chitosan.

These results are in harmony with a previous study were conducted to find out the effects of Aloe vera gel and chitosan on postharvest quality of mango fruit cv. Chok Anan. It was found that, at $25^{\circ} \mathrm{C}$ storage temperature, fruit coated with $1 \%$ chitosan and $20 \%$ Aloe vera gel had less disease symptoms and longer storage life than the non-coated fruit (Mongkon Intalook., 2005).Furthermore, the effect of gum Arabic (GA) $10 \%$ and chitosan $(\mathrm{CH})$ 1\% edible coatings on physiological and biochemical properties of mango (Mangifera indica L. cv. Choke Anan) fruit were investigated by (Khaliq et al., 2016). They reported that no significant differences can be seen between $\mathrm{CH} 1 \%$ and GA $10 \%+\mathrm{CH} 1 \%$ treated fruits throughout the storage period. The highest decay percentage was recorded in the control samples at the end of storage period. It has been observed that coating has the ability to prevent the growth of fungi in wide horticultural produces (Tripathi and Dubey, 2004). Several strategies have been evaluated by using natural bio preservatives instead of fungicides to inhibit decay development and delay the ripening process of mango fruit. Chitosan has strong antimicrobial and antifungal properties and helps to prevent postharvest fruit diseases (Elsabee and Abdou, 2013).

Table. 2: Effect of chitosan, gum Arabic and Aloe vera gel postharvest treatments on disorders percentage of "Alphonse" mango fruits during cold storage at $\left(13 \pm 1{ }^{\circ} \mathrm{C}\right.$ and $90-95 \%$ R.H.) in 2017 and 2018 seasons.

\begin{tabular}{|c|c|c|c|c|c|}
\hline \multirow{3}{*}{ A- Treatments } & \multicolumn{5}{|c|}{ B- Storage Periods (Days) } \\
\hline & $\mathbf{0}$ & 10 & 20 & 30 & Means (A) \\
\hline & \multicolumn{5}{|c|}{ Season 2017} \\
\hline Control & 0.00 & 2.75 & 4.37 & 6.59 & 3.43 \\
\hline Chitosan (1\%) & 0.00 & 0.96 & 1.35 & 1.68 & 0.99 \\
\hline Chitosan (2\%) & 0.00 & 0.67 & 1.09 & 1.25 & 0.76 \\
\hline Gum Arabic (5\%) & 0.00 & 1.09 & 1.43 & 1.82 & 1.08 \\
\hline Aloe vera Gel (25\%) & 0.00 & 1.22 & 3.13 & 5.78 & 2.53 \\
\hline Aloe vera Gel (50\%) & 0.00 & 1.11 & 2.88 & 5.38 & 0.76 \\
\hline Means (B) & $\mathbf{0 . 0 0}$ & 1.25 & 2.20 & 3.41 & \\
\hline \multirow[t]{2}{*}{$\mathbf{L S D}_{\text {at } 0.05}$} & \multicolumn{5}{|c|}{ Treatments $(\mathrm{A}): 0.13$ Storage Periods $(\mathrm{B}): 0.09$ Interaction $(\mathrm{A} \times \mathrm{B}): 0.25$} \\
\hline & \multicolumn{5}{|c|}{ Season 2018} \\
\hline Gum Arabic (5\%) & 0.00 & 1.22 & 1.34 & 1.78 & 1.08 \\
\hline Gum Arabic (10\%) & 0.00 & 0.84 & 1.13 & 1.33 & 0.82 \\
\hline Aloe vera Gel (25\%) & 0.00 & 1.26 & 3.05 & 5.93 & 2.56 \\
\hline Aloe vera Gel (50\%) & 0.00 & 0.90 & 2.87 & 5.37 & 2.29 \\
\hline Means (B) & $\mathbf{0 . 0 0}$ & 1.32 & 2.21 & 3.49 & \\
\hline LSD at 0.05 & \multicolumn{5}{|c|}{ Treatments (A): 0.15 Storage Periods $(B): 0.12$ Interaction $(A \times B): 0.31$} \\
\hline
\end{tabular}

\section{Fruit firmness}

Data of studying the effect of chitosan, gum Arabic and Aloe vera gel postharvest treatments during cold storage on fruit firmness of mango (Mangifera indica L. cv. Alphonse) in 2017 and 2018 seasons was reported in Table (3). Data showed that fruit firmness decreased with increasing storage periods, and the differences among all tested storage periods were statistically significant compared with the initial date in the two seasons of study.

Moreover, chitosan, gum Arabic and Aloe Vera gel treatments significantly increased fruit firmness compared with untreated fruits (control) in 2017 and 2018 seasons. In addition, the treatments of gum Arabic at $10 \%$ and Aloe vera gel at 50\% were more effective and significant on increasing fruit firmness during cold storage compared with other treatments. Losses in firmness with 
the progress of storage period due to ripening of mango fruits as a result of an increase in activities of cell wall hydrolysis enzymes such as pectinesterase, polygalacturonase pectin methylesterase and pectatelyases during ripening and cold storage (Ali et al., 2004). In the cell wall, hydrolyzing enzymes are enhanced by $\mathrm{CO}_{2}$ production in climacteric fruits (Abbasi et al., 2009; Zhu et al., 2008; De S. Medeiros et al., 2012; Hong et al., 2012; Yu et al., 2012; Elsabee \& Abdou, 2013 and Shi et al., 2013). Moreover, chitosan, gum Arabic and Aloe vera treatments alter gas diffusion and thus the exchange of $\mathrm{CO}_{2}$ and $\mathrm{O}_{2}$ exchange between fruit tissue and the outside atmosphere, maintaining fruit moisture and reducing the normal metabolic activity consequently, delay textural changes and reduce ripening process in mango (Wang et al., 2007 and Zhu et al., 2008).In a previous study was conducted to find out the effects of Aloe vera gel and chitosan on postharvest quality of mango fruit cv. Chok Anan. It was found that, at $25^{\circ} \mathrm{C}$ storage temperature, fruit coated with $1 \%$ chitosan and $20 \%$ Aloe vera gel could delay fruit firmness changes of coated fruit than the other treatments (Mongkon Intalook, 2005).

Table. 3: Effect of chitosan, gum Arabic and Aloe Vera gel postharvest treatments on firmness $\left(\mathrm{lb} /\right.$ inch $\left.^{2}\right)$ of "Alphonse" mango fruits during cold storage at $\left(13 \pm 1^{\circ} \mathrm{C}\right.$ and $90-95 \%$ R.H.) in 2017 and 2018 seasons.

\begin{tabular}{|c|c|c|c|c|c|}
\hline \multirow{3}{*}{ A- Treatments } & \multicolumn{5}{|c|}{ B- Storage Periods (Days) } \\
\hline & $\mathbf{0}$ & 10 & 20 & 30 & Means (A) \\
\hline & \multicolumn{5}{|c|}{ Season 2017} \\
\hline Control & 11.55 & 8.91 & 4.94 & 2.44 & 6.96 \\
\hline Chitosan (1\%) & 11.55 & 9.98 & 7.22 & 4.60 & 8.33 \\
\hline Chitosan (2\%) & 11.55 & 12.55 & 8.15 & 5.21 & 8.98 \\
\hline Gum Arabic (5\%) & 11.55 & 11.03 & 7.68 & 4.78 & 8.64 \\
\hline Aloe vera Gel (25\%) & 11.55 & 10.36 & 7.40 & 4.53 & 8.46 \\
\hline Aloe vera Gel (50\%) & 11.55 & 10.89 & 8.47 & 5.36 & 9.07 \\
\hline Means (B) & 11.55 & 10.41 & 7.51 & 4.64 & \\
\hline \multirow[t]{2}{*}{ LSD $_{\text {at } 0.05}$} & \multicolumn{5}{|c|}{ Treatments (A): 0.24 Storage Periods $(\mathrm{B}): 0.18$ Interaction $(\mathrm{A} \times \mathrm{B}): 0.40$} \\
\hline & \multicolumn{5}{|c|}{ Season 2018} \\
\hline Gum Arabic (5\%) & 12.15 & 10.29 & 7.38 & 4.15 & 8.49 \\
\hline Gum Arabic (10\%) & 12.15 & 10.83 & 8.25 & 5.18 & 9.10 \\
\hline Aloe vera Gel (25\%) & 12.15 & 10.12 & 7.16 & 4.04 & 8.37 \\
\hline Aloe vera Gel (50\%) & 12.15 & 10.62 & 8.12 & 4.94 & 8.96 \\
\hline Means (B) & $\mathbf{1 2 . 1 5}$ & 10.12 & 7.27 & 4.22 & \\
\hline
\end{tabular}

Furthermore, loss of firmness during storage is agreement with the findings of Wongmetha and ke (2012), Figueroa et al. (2011) and Nongtaodum and Jangchud (2009), who found that chitosan played a positive role in this regard by delaying firmness loss. Kays (1991) attributed fruit softness to enzymatically mediated degredative changes in cell walls during ripening. Pectinmethylesterase (PME) and polygalacturonase (PG) might be either synthesized or activated or a combination of both at or near the onset of ripening. Figueroa et al. (2011) results also showed that chitosan played a positive role in decreasing firmness loss.

\section{Total soluble solids}

Data concerning the effect of chitosan, gum Arabic and Aloe vera gel postharvest treatments during cold storage total soluble solids content of mango (Mangifera indica, L. cv. Alphonse), in 2017 and 2018 seasons are reported in Table (4). Results, generally, showed that fruit total soluble solids content was gradually increased and significantly with the progress of storage and reached the highest significant level at the end of storage period compared with fruits at harvest. The higher increment of mango fruits content in TSS with the progress of storage period could be attributed to hydrolysis of carbohydrates to sugars because of moisture loss and decrease in acidity (Golding et al., 2005).In this 
regard, the effect of storage period on fruit TSS content gradually increased with storage. This could be due to the losses in water through the respiration and evaporation during storage and hence the losses in fruit weight (Ezz and Awad, 2011).

Table 4: Effect of chitosan, gum Arabic and Aloe vera gel postharvest treatments on total soluble solids percentage of "Alphonse" mango fruits during cold storage at $\left(13 \pm 1^{\circ} \mathrm{C}\right.$ and $90-95 \%$ R.H.) in 2017 and 2018 seasons.

\begin{tabular}{|c|c|c|c|c|c|}
\hline \multirow{3}{*}{ A- Treatments } & \multicolumn{5}{|c|}{ B- Storage Periods (Days) } \\
\hline & $\mathbf{0}$ & 10 & 20 & 30 & Means (A) \\
\hline & \multicolumn{5}{|c|}{ Season 2017} \\
\hline Control & 12.72 & 14.08 & 16.14 & 17.93 & 15.22 \\
\hline Chitosan (1\%) & 12.72 & 15.12 & 16.87 & 19.02 & 15.93 \\
\hline Chitosan (2\%) & 12.72 & 15.65 & 17.45 & 19.35 & 16.29 \\
\hline Gum Arabic (5\%) & 12.72 & 14.75 & 16.74 & 18.81 & 15.75 \\
\hline Aloe vera Gel (25\%) & 12.72 & 16.05 & 17.14 & 19.95 & 16.46 \\
\hline Aloe vera Gel (50\%) & 12.72 & 16.17 & 17.56 & 20.55 & 16.87 \\
\hline Means (B) & 12.72 & 15.39 & $\mathbf{1 7 . 0 2}$ & 19.27 & \\
\hline \multirow[t]{2}{*}{ LSD $_{\text {at } 0.05}$} & \multicolumn{5}{|c|}{ Treatments (A): 0.17 Storage Periods $(B): 0.13$ Interaction $(A \times B): 0.35$} \\
\hline & \multicolumn{5}{|c|}{ Season 2018} \\
\hline Gum Arabic (5\%) & 13.35 & 15.18 & 17.09 & 19.02 & 16.16 \\
\hline Gum Arabic (10\%) & 13.35 & 15.58 & 17.51 & 19.40 & 16.46 \\
\hline Aloe vera Gel (25\%) & 13.35 & 16.22 & 17.33 & 20.30 & 16.80 \\
\hline Aloe vera Gel (50\%) & 13.35 & 17.00 & 17.87 & 20.69 & 17.23 \\
\hline Means (B) & 13.35 & 15.55 & 17.22 & 19.38 & \\
\hline LSD at 0.05 & \multicolumn{5}{|c|}{ Treatments (A): 0.13 Storage Periods $(B): 0.10$ Interaction $(A \times B): 0.26$} \\
\hline
\end{tabular}

Our results also, revealed that, all treatments significantly increased total soluble solids contents compared with the control. In addition, Statistical analysis of the present data indicated that, Aloe vera gel at 50\% treatment caused a higher effect in increasing total soluble solids than those other treatments and the differences were big enough to be significant. Effect of gum Arabic (GA) 10\% and chitosan $(\mathrm{CH}) 1 \%$ edible coatings on physiological and biochemical properties of mango (Mangifera indica L. cv. Choke Anan) fruit were investigated by Khaliq et al., 2016. They reported that soluble solid concentration gradually increased in all samples regardless of dipping treatments with increasing the storage time. It has been reported that SSC increased with progressing the storage time in nectarine (Ahmed et al., 2009) and mango (Zheng et al., 2012; Li et al., 2014). These data support previous reports, where a minor increase in SSC has been reported in shiitake mushroom treated with gum Arabic plus natamycin (Jiang et al., 2013) and chitosan coated mango (Kittur et al., 2001; de S. Medeiros et al., 2012). The increase in SSC could be attributed by the breakdown of carbohydrate into simple sugar and glucose (Kittur et al., 2001). During the ripening process, starch hydrolyzed into simple sugars, where glucose, fructose and sucrose are dominant in ripe fruits (Ito et al., 1997). The activities of sucrose synthase, invertase and amylase enzyme increased and hydrolysed the starch to sucrose (Kumar et al., 1994). Edible coating created a semipermeable film around the fruit and modified the internal atmosphere by increasing $\mathrm{CO}_{2}$ and decreasing $\mathrm{O}_{2}$ production (De $\mathrm{S}$. Medeiros et al., 2012).

\section{Titratable acidity}

The response of titratable acidity content on mango (Mangifera indica L. cv. Alphonse) fruits to postharvest application of chitosan, gum Arabic and Aloe vera gel was reported in Table (5). Data showed that, in both seasons, all treatments caused a significant decrease in titratable acidity compared with control. In addition, the statistical analysis showed that, chitosan at $2 \%$ in first season and Aloe vera gel at 50\% in both seasons caused a higher effect in decreasing titratable acidity than that other treatments and the differences were big enough to be significant. 
Regarding the effect of storage periods on the changes in fruit titratable acidity content were significantly decreased with increasing storage periods, and the differences among all tested storage periods were statistically significant compared with the initial date in the two seasons of study. The titratable acidity gradually declined with the increase in storage duration that is due to the consumption of organic acids in respiratory metabolism (Pesis et al., 1999; Abbassi et al., 2009; Rab et al., 2011). In addition, it is due to the conversion of citric acid into sugars and their further utilization in metabolic process of the fruits, Doreyappy-Gowda \& Huddar, 2001 and Rathore et al., 2007). In a previous study was conducted to find out the effects of Aloe vera gel and chitosan on postharvest quality of mango fruit cv. Chok Anan. It was found that, at $25^{\circ} \mathrm{C}$ storage temperature, fruit coated with $1 \%$ chitosan and $20 \%$ Aloe vera gel could delay fruit titratable acidity changes of coated fruit than the other treatments (Mongkon Intalook, 2005).Furthermore, the effect of coating with chitosan on mango cv. 'Zibda' fruit storability was study by Mohamed et al., (2017) and they reported that mango fruit contents in TA gradually and significantly decreased with the advanced of storage period during the two seasons in this trial. Data also cleared that, all pre-harvest coating applications significantly reduced titratable acidity fruit contents changing rate during cold storage. A rapid reduction in TA content of mango fruits during storage is associated with fast senescence of fruits (Abbasi et al., 2009).

Table 5: Effect of chitosan, gum Arabic and Aloe vera gel postharvest treatments on titratable acidity percentage of "Alphonse" mango fruits during cold storage at $\left(13 \pm 1^{\circ} \mathrm{C}\right.$ and $90-95 \%$ R.H.) in 2017 and 2018 seasons.

\begin{tabular}{|c|c|c|c|c|c|}
\hline \multirow{3}{*}{ A- Treatments } & \multicolumn{5}{|c|}{ B- Storage Periods (Days) } \\
\hline & $\mathbf{0}$ & 10 & 20 & 30 & Means (A) \\
\hline & \multicolumn{5}{|c|}{ Season 2017} \\
\hline Control & 2.10 & 1.74 & 0.93 & 0.69 & 1.37 \\
\hline Chitosan (1\%) & 2.10 & 1.72 & 0.78 & 0.44 & 1.26 \\
\hline Chitosan (2\%) & 2.10 & 1.57 & 0.64 & 0.40 & 1.18 \\
\hline Gum Arabic (5\%) & 2.10 & 1.79 & 0.89 & 0.59 & 1.35 \\
\hline Gum Arabic (10\%) & 2.10 & 1.68 & 0.75 & 0.48 & 1.25 \\
\hline Aloe vera Gel (25\%) & 2.10 & 1.65 & 0.71 & 0.40 & 1.21 \\
\hline Aloe vera Gel (50\%) & 2.10 & 1.52 & 0.61 & 0.38 & 1.15 \\
\hline Means (B) & 2.10 & 1.67 & 0.76 & 0.48 & \\
\hline \multirow[t]{2}{*}{ LSD $_{\text {at } 0.05}$} & \multicolumn{5}{|c|}{ Treatments $(A): 0.03$ Storage Periods $(B): 0.02$ Interaction $(A \times B): 0.07$} \\
\hline & \multicolumn{5}{|c|}{ Season 2018} \\
\hline Control & 1.95 & 1.81 & 0.97 & 0.69 & 1.35 \\
\hline Chitosan (1\%) & 1.95 & 1.70 & 0.75 & 0.51 & 1.23 \\
\hline Chitosan (2\%) & 1.95 & 1.60 & 0.66 & 0.46 & 1.17 \\
\hline Gum Arabic (5\%) & 1.95 & 1.88 & 0.87 & 0.64 & 1.33 \\
\hline Gum Arabic (10\%) & 1.95 & 1.72 & 0.77 & 0.61 & 1.26 \\
\hline Aloe vera Gel (25\%) & 1.95 & 1.67 & 0.69 & 0.44 & 1.19 \\
\hline Aloe vera Gel (50\%) & 1.95 & 1.54 & 0.59 & 0.40 & 1.12 \\
\hline Means (B) & 1.95 & 1.70 & 0.75 & 0.54 & \\
\hline LSD $_{\text {at } 0.05}$ & \multicolumn{5}{|c|}{ Treatments $(A): 0.04$ Storage Periods $(B): 0.03$ Interaction $(A \times B): 0.07$} \\
\hline
\end{tabular}

Studying the efficacy of chitosan, gum acacia, guar gum, and paraffin is well established as an effective edible coating on Ber fruits by Mani et al., (2018). Results showed that the fall in titratable acidity was highest in case of control which was 11.47 at 0 day to 8.1 at $15^{\text {th }}$ day of storage. The reduction in acidity content was however lowest in case of coated fruit samples as compared to the uncoated ones. At $15^{\text {th }}$ storage day, lowest fall of acidity was observed in T3 (Aloe vera gel at $2 \%+$ Guar gum at 2\%) which was 9.57 followed by T5 (Aloe vera gel at2\% + Paraffin at 2\%) which was 9.23. Maximum reduction in acidity was observed in T1 (Control) sample which was 8.1 followed by T6 (Chitosan at2\%) which was 8.43 .

\section{Total sugars}

Data concerning the influence of postharvest application of chitosan, gum Arabic and Aloe vera gelon fruit total sugars of mango (Mangifera indica L. cv. Alphonse) are reported in Table (6). Data 
showed that, in both seasons, all treatments caused a significant increase in total sugars compared with the control. In addition, statistical analysis of the present data indicated that, Aloe vera gel at $50 \%$ treatment caused a higher effect in increasing fruit total sugars content than those other treatments and the differences were big enough to be significant.

Regarding the effect of storage periods, data show that, fruit total sugars content was gradually increased and significantly as storage prolonged the rate of respiration, transpiration and other metabolic changes (Gul et al., 1990), and reached the highest significant level at the end of storage period compared with fruits at zero time. The increase in sugars content during storage may possibly be due to hydrolysis of starch into sugars as on complete hydrolysis of starch no further increase occurs and subsequently a decline in these parameters is predictable as they along with other organic acids are primary substrate for respiration (Will et al., 1980). In this regard, Wongmetha and ke (2012) reported that starch content of mango fruits tended to decrease during storage and attributed that decrease to the conversion of starch to sucrose.

Table. 6: Effect of chitosan, gum Arabic and Aloe vera gel postharvest treatments on total sugars (g. glucose per $100 \mathrm{~g}$. fresh weight $)$ of "Alphonse" mango fruits during cold storage at $\left(13 \pm 1^{\circ} \mathrm{C}\right.$ and $90-95 \%$ R.H.) in 2017 and 2018 seasons.

\begin{tabular}{|c|c|c|c|c|c|}
\hline \multirow{3}{*}{ A- Treatments } & \multicolumn{5}{|c|}{ B- Storage Periods (Days) } \\
\hline & $\mathbf{0}$ & 10 & 20 & 30 & Means (A) \\
\hline & \multicolumn{5}{|c|}{ Season 2017} \\
\hline Control & 4.85 & 6.56 & 12.53 & 14.20 & 9.54 \\
\hline Chitosan (1\%) & 4.85 & 7.05 & 12.89 & 14.74 & 9.88 \\
\hline Chitosan (2\%) & 4.85 & 7.38 & 13.26 & 15.13 & 10.15 \\
\hline Gum Arabic (5\%) & 4.85 & 6.95 & 12.65 & 14.55 & 9.75 \\
\hline Gum Arabic (10\%) & 4.85 & 7.27 & 12.99 & 14.91 & 10.01 \\
\hline Aloe vera Gel (25\%) & 4.85 & 7.31 & 13.14 & 15.07 & 10.09 \\
\hline Aloe vera Gel (50\%) & 4.85 & 7.55 & 13.47 & 15.37 & 10.31 \\
\hline Means (B) & 4.85 & 7.15 & 12.99 & 14.85 & \\
\hline \multirow[t]{2}{*}{ LSD $_{\text {at } 0.05}$} & \multicolumn{5}{|c|}{ Treatments $(\mathrm{A})$ : 0.19 Storage Periods $(\mathrm{B}): 0.15$ Interaction $(\mathrm{A} \times \mathrm{B}): 0.31$} \\
\hline & \multicolumn{5}{|c|}{ Season 2018} \\
\hline Control & 5.45 & 6.77 & 11.87 & 13.90 & 9.50 \\
\hline Chitosan (1\%) & 5.45 & 7.45 & 12.47 & 14.77 & 10.03 \\
\hline Chitosan $(2 \%)$ & 5.45 & 7.69 & 13.32 & 15.10 & 10.39 \\
\hline Gum Arabic (5\%) & 5.45 & 7.08 & 12.28 & 14.43 & 9.81 \\
\hline Gum Arabic (10\%) & 5.45 & 7.55 & 12.70 & 14.55 & 10.06 \\
\hline Aloe vera Gel $(25 \%)$ & 5.45 & 7.65 & 12.68 & 15.01 & 10.19 \\
\hline Aloe vera Gel (50\%) & 5.45 & 7.79 & 13.35 & 15.44 & 10.56 \\
\hline Means (B) & 5.45 & 7.42 & 12.69 & 14.74 & \\
\hline LSD $_{\text {at } 0.05}$ & \multicolumn{5}{|c|}{ Treatments $(A): 0.15$ Storage Periods $(B): 0.11$ Interaction $(A \times B): 0.30$} \\
\hline
\end{tabular}

Studying the efficacy of chitosan, gum acacia, guar gum, and paraffin is well established as an effective edible coating on Ber fruits by Mani et al., (2018). Results showed that the total sugar content increased in of the fruits during the storage period. The total sugar content in untreated fruits showed an increase as the storage duration is prolonged. In control sample, total sugar content increased from 8.26 at day 0 to 11.51 at $15^{\text {th }}$ day of storage. The treated samples showed a lesser decline in the total sugar content. Minimum fall in total sugar content was observed in T3 (Aloe vera gel at $2 \%+$ Guar gum at $2 \%$ ) which was 8.37 in day 0 to 11.93 in day 15 . However there was no significant effect of treatment on the total sugar content of the fruits. The increase in total sugar content is dependent of the type of edible coating treatment employed. The increase in total sugar content can be attributed to the fact that starch gets transformed to sugar during the storage period. The noteworthy surge in total sugars content during their storage is credited to the proliferation in the enzymatic activity accountable for starch hydrolysis and sugar breakdown due to respiration.

\section{Vitamin C}

Results of the present investigation, presented in Table (7) showed the effect of postharvest application of chitosan, gum Arabic and Aloe vera gel on fruit vitamin $\mathrm{C}$ contents of mango 
(Mangifera indica L. cv. Alphonse) during cold storage in 2017 and 2018 seasons.The results revealed that, in both seasons, fruit vitamin $\mathrm{C}$ content was gradually decreased and significantly with the progress of storage and reached the lowest significant level at the end of storage period compared with initial date.The rapid reduction of mango fruit content in ascorbic acid during storage is associated with the fast senescence of fruits (Abbasi et al., 2009).

The statistical analysis also, revealed that, all treatments significantly increased fruit ascorbic acid contents compared with control. Moreover, chitosan at 2\% and Aloe vera gel at 50\% caused a higher effect in increasing ascorbic acid than those other treatments and the differences were big enough to be significant. Coating treatments served as a protective layer and controlled the permeability of oxygen and carbon dioxide, thus led to change the internal atmosphere of the fruits, which delayed the metabolic processes and consequently retarded fruit senescence. Thereby delayed the deteriorative oxidation reaction of ascorbic acid (Wang et al., 2007; Zhu et al., 2008; Abbasiet al., 2009; De S. Medeiros et al., 2012; Hong et al., 2012; Yu et al., 2012; Shi et al., 2013; Wang et al., 2014 and Kumari et al., 2015).Therefore, treated mango fruit with chitosan coatings treatments could be inhibited the metabolic processes and delayed the declined in ascorbic acid content of mango fruits during storage. Moreover, the loss in ascorbic acid content during storage could be attributed to the increase in ascorbate oxidase activity and conversion of L-ascorbic acid into dihydro-ascorbic acid (Cardello\& Cardello, 1998 and Davey et al., 2000). Furthermore, the effect of gum Arabic (GA) 10\% and chitosan $(\mathrm{CH}) 1 \%$ edible coatings on physiological and biochemical properties of mango (Mangifera indica L. cv. Choke Anan) fruit were investigated by Khaliq et al., 2016. They reported that, in general, a gradual decline in ascorbic acid was observed during storage in both treated and untreated mango fruit. The highest loss of ascorbic acid was recorded in the control fruits at the end of experiment.

Table. 7: Effect of chitosan, gum Arabic and Aloe vera gel postharvest treatments on vitamin C (mg ascorbic acid per $100 \mathrm{ml}$ juice $)$ of "Alphonse" mango fruits during cold storage at $\left(13 \pm 1^{\circ} \mathrm{C}\right.$ and $90-95 \%$ R.H.) in 2017 and 2018 seasons.

\begin{tabular}{|c|c|c|c|c|c|}
\hline \multirow{3}{*}{ A- Treatments } & \multicolumn{5}{|c|}{ B- Storage Periods (Days) } \\
\hline & $\mathbf{0}$ & 10 & 20 & 30 & Means (A) \\
\hline & \multicolumn{5}{|c|}{ Season 2017} \\
\hline Control & 42.25 & 34.75 & 27.68 & 21.65 & 31.58 \\
\hline Chitosan (1\%) & 42.25 & 36.74 & 30.78 & 25.66 & 33.86 \\
\hline Chitosan (2\%) & 42.25 & 37.41 & 33.34 & 27.27 & 35.07 \\
\hline Gum Arabic (5\%) & 42.25 & 36.03 & 30.04 & 24.84 & 33.29 \\
\hline Aloe vera Gel (25\%) & 42.25 & 35.86 & 30.42 & 25.22 & 33.43 \\
\hline Aloe vera Gel (50\%) & 42.25 & 37.18 & 32.60 & 27.00 & 34.76 \\
\hline Means (B) & 42.25 & 36.39 & 30.89 & 25.47 & \\
\hline LSD $_{\text {at } 0.05}$ & \multicolumn{5}{|c|}{ Treatments $(\mathrm{A}): 0.59$ Storage Periods $(\mathrm{B}): 0.45$ Interaction $(\mathrm{A} \times \mathrm{B}): 1.10$} \\
\hline \multicolumn{6}{|c|}{ Season 2018} \\
\hline Gum Arabic (5\%) & 40.65 & 36.65 & 30.98 & 25.61 & 33.47 \\
\hline Gum Arabic (10\%) & 40.65 & 36.95 & 32.58 & 27.18 & 34.34 \\
\hline Aloe vera Gel (25\%) & 40.65 & 37.47 & 31.93 & 26.07 & 34.03 \\
\hline Aloe vera Gel (50\%) & 40.65 & 38.61 & 33.73 & 28.30 & 35.32 \\
\hline Means (B) & 40.65 & $\mathbf{3 7 . 0 3}$ & 31.79 & 26.02 & \\
\hline
\end{tabular}

LSDat $0.05 \quad$ Treatments (A): 0.46 Storage Periods (B): 0.35 Interaction (A $\times$ B): 0.92

\section{Conclusion}

The present study illustrated that, postharvest coating of chitosan, gum Arabic and Aloe vera gel treatments as applications are the promising strategy for the management postharvest fruit quality of mangoes cv. "Alphonse" during storage at $13^{\circ} \mathrm{C}$ and increased its storage life up to Four weeks. In addition, chitosan at $2 \%$ and Aloe vera gel at $50 \%$ led to market increase in firmness, TSS, titratable 
acidity, total sugars and vitamin $\mathrm{C}$, where, gum Arabic at 10\% caused a highly minimized fruit weight loss and disorders percentage compared with others.

\section{References}

A.O.A.C., 1980. Official methods of analytical Chemists Washington, D.C., U.S.A.

A.O.A.C., 1994. Officials methods of analysis. $14^{\text {th }}$. Edition. Williams. Ed. Published by the Association of Analytical Chemists. 1111 North $19^{\text {th }}$ Street, Suite 20, $16^{\text {th }}$ Edi. Arlington, Virginia, USA. 22209.

A.O.A.C., 1999. Official's methods of analysis. $14^{\text {th }}$. Edition. Williams. Ed. Published by the Association of Analytical Chemists. Washington, D. C., p. 1141.

Abbasi, N.A., Z.M. Iqbal, M. Maqbool, and I.A. Hafiz, 2009. Postharvest quality of mango (Mangifera indica, L.) fruit as affected by chitosan coating. Pakistan Journal of Botany 41, 343-357.

Ahmed, M.J., Z. Sing and A.S. Khan, 2009. Postharvest Aloe vera gel-coating modulates fruit ripening and quality of 'Arctic Snow' nectarine kept in ambient and cold storage. International Journal of Food Science and Technology 44(5): 1024-1033.

Aider, M., 2010. Chitosan application for active bio-based films production and potential in the food industry: Review. LWT-Food Science and Technology, 43(6): 837-842.

Ali, A., M. Maqbool, S. Ramachandran and P.G. Alderson, 2010. Gum arabic as a novel edible coating for enhancing shelf-life and improving postharvest quality of tomato (Solanum lycopersicum L.) fruit. Postharvest Biology and Technology, 58(1): 42-47.

Ali, Z.M., L.H. Chin and H. Lazan, 2004. A comparative study on wall degrading enzymes, pectin modifications and softening during ripening of selected tropical fruits. Plant Science, 167, 317327.

Cardello, H.M.A.B. and L. Cardello, 1998. Vitamin C, ascorbate oxidase activity and sensory profile of mango (Mangifera indica L.) var. Haden during ripening. Cienciae Tecnologia de Alimentos, 18 (2), 211-217.

Castillo, S., D. Navarro, P.J. Zapata, F. Guillen, D. Valero, M. Serrano and D. Martinez-Romero, 2010. Antifungal efficacy of Aloe vera in vitro and its use as a pre-harvest treatment to maintain postharvest table grape quality. Postharvest Biol. Technol., 57: 183-188.

Davey, M.W., M. Van Montagu, D. Inze, M. Sanmartin, A. Kanellis, and N. Smirnoff, 2000. Plant Lascorbic acid: Chemistry, function, metabolism, bioavailability and effects of processing. J. Sci. Food. Agric., 80, 825-860.

De, S. Medeiros, B.G., A.C. Pinheiro, M.G. Carneiro-da-Cunha and A.A. Vicente, 2012. Development and characterization of a nanomultilayer coating of pectin and chitosan evaluation of its gas barrier properties and application on 'Tommy Atkins' mangoes. Journal of Food Engineering 110(3): 457-464.

Devlieghere, F., A. Vermeulen and J. Debevere, 2004. Chitosan: antimicrobial activity, interactions with food components and applicability as a coating on fruit and vegetables. Food Microbiology, 21(21): 703-714.

Doreyappy-Gowda, I.N.D. and A.G. Huddar, 2001. Studies on ripening changes in mango (Mangifera indica L.) fruits. Journal of Food Science and Technology Mysore, 38, 135-137.

Elsabee, M.Z. and E.S. Abdou, 2013. Chitosan based edible films and coatings: A review. Materials Science and Engineering C, 33 (4), 1819-1841.

Ezz, Thanaa M. and R.M. Awad, 2011. Effect of some postharvest treatments under different low temperature on two mango cultivars. Australian Journal of Basic and Applied Science 5(10), 1164-1174.

Figueroa, M.S., W.I.A. Gómez, E.H. Ortiz, J.A.V. Ovando and M.D.L.A. Anaya, 2011. Effect of chitosan coating on some characteristics of mango (Mangifera indica, L.) "Ataulfo" subjected to hydrothermal process. African Journal of Agricultural Research, 6(27): 5800-5807.

Golding, J.B., J.H. Ekman, and M.C. Glasson, 2005. Regulation of fruit ripening. Stewart Postharvest Review. Postharvest Biology and Technology, 3, 1-5.

Gomez, K.A. and A.A. Gomez, 1984. Statistical procedure for agricultural research. $2^{\text {nd }}$ Edition. pp. 8-22. 
González-Aguilar, G., E. Valenzuela-Soto, J. Lizardi-Mendoza, M. Goycoolea, M. Martínez-Téllez, M. Villegas-Ochoa, I. Monroy-García and F. Ayala-Zavala, 2009. Effect of chitosan coating in preventing deterioration and preserving the quality of fresh-cut papaya 'Maradol'. J. Sci. Food Agric., 89, 15-23.

Gul, S., M. Ishtiaq and S.H. Shah. 1990. Studies on the effect of storage on the quality of sweet orange. Sarhad. J. Agri., 6(5): 433-436.

Hong, K.Q., J.H. Xie, L.B. Zhang, D.Q. Sun and D.Q. Gong, 2012. Effects of chitosan coating on postharvest life and quality of guava (Psidium guajava, L.) fruit during cold storage. Sci. Hortic., 144, 172-178.

Ito, T., K. Sasaki and Y. Yoshida, 1997. Changes in respiration rate, saccharide and organic acid content during the development and ripening of mango fruit (Mangifera indica L. 'Irwin') cultured in a plastic house. Journal of the Japanese Society for Horticultural Science 66(3-4): 629-635.

Jiang, T., L. Feng, X. Zheng and J. Li, 2013. Physicochemical responses and microbial characteristics of shiitake mushroom (Lentinus edodes) to gum Arabic coating enriched with natamycin during storage. Food Chemistry, 138(2-3): 1992-1997.

Jiang, Y. and Y. Li, 2001. Effects of chitosan coating on postharvest life and quality of longan fruit. Food Chem., 73, 139-143.

Kays, S.J., 1991. Postharvest physiology of perishable plant products. New York: Van Nostrand Reinhold, p. 532.

Khaliq, G., M.T.M. Mohamed, P. Ding, H.M. Ghazali and A. Ali, 2016. Storage behaviour and quality responses of mango (Mangifera indica L.) fruit treated with chitosan and gum arabic coatings during cold storage conditions. International Food Research Journal 23(Suppl): S141S148.

Kittur, F., N. Saroja, Habibunnisa and R.N. Tharanathan, 2001. Polysaccharide-based composite coating formulations for shelf-extension of fresh banana and mango. European Food Research and Technology 213(4): 306-311.

Kumar, S., D.K. Das, A.K. Singh, and U.S. Prasad, 1994. Sucrose metabolism during maturation and ripening of mango cultivars. Plant Physiology and Biochemistry 21(1): 27-32.

Kumari, P., K. Barmana, V.B. Patel, M.W. Siddiqui and B. Kolec, 2015. Reducing postharvest pericarp browning and preserving health promoting compounds of litchi fruit by combination treatment of salicylic acid and chitosan. Scientia Horticulture, 197, 555-563.

Li, P., X. Zheng, Y. Liu and Y. Zhu, 2014. Pre-storage application of oxalic acid alleviates chilling injury in mango fruit by modulating proline metabolism and energy status under chilling stress. Food Chemistry 142: 72-78.

Malik, C.P. and M.B. Singh, 1980.Plant enzymology and histoenzymology. A text Manual Kalyani Pubishers, New Delhi.

Mani, A., V.S.S.V. Prasanna, S. Halder and J. Praveena, 2018. Efficacy of edible coatings blended with aloe Vera in retaining post-harvest quality and improving storage attributes in Ber (Ziziphus mauritiana Lamk.). International Journal of Chemical Studies. 6(6): 1727-1733.

Martinez-Romero, D., N. Alburquerque, J. M. Valverde, F. Guillen, S. Castillo and D. Valero, 2006. Postharvest sweet cherry quality and safety maintenance by Aloe vera treatment: a new edible coating. Postharvest Biology and Technology, 39: 93-100.

Mohamed, M.A.A., A.F. Abd El-Khalek and H.G. Elmehrat, 2017. Pre-Harvest Applications of Potassium Silicate, Chitosan and Calcium Chloride to Improve Mango cv. 'Zibda' Fruit Quality and Storability. Egypt. J. Hort., 44(1):17 - 32.

MongkonIntalook, 2005. Effect of Aloe vera gel, chitoson and carnauba wax coating on post harvest quality of mango fruits cv. Chok Anon. Post harvest Technology Institute Chiang mai University. 167.

Nongtaodum, S. and A. Jangchud, 2009. Effects of edible chitosan coating on quality of fresh-cut mangoes (Falun) during storage. Kasetsart J. (Nat. Sci.) 43: 282-289.

Pesis, E., O. Dvir, O. Feygenberg, R.B. Arie, M. Ackerman and Lichter. 1999. Production of acetaldehyde and ethanol during maturation and modified atmosphere storage of litchi fruit. 
Postharvest Biology and Technolgy 26, 157-165. http://dx.doi.org/10.1016/S09255214(02)00024-8

Prusky, D. and N.T. Keen, 1993. Involvement of preformed antifungal compounds and the resistance of subtropical fruits to fungal decay. Plant Disease, 77, 114-119.

Rab, A., M. Sajid, Saeeda and Najia. 2011. Effects of wet heat treatment (WHT) durations on the quality of sweet orange stored at room temperature. Sarhad Journal of Agriculture 27(2), 189194.

Rathore, H. A., T. Masud, S. Sammi and H.A. Soomro, 2007. Effect of storage on physico-chemical composition and sensory properties of mango (Mangifera indica L.) variety Dosehari. Pakistan Journal of Nutrition, 6 (2), 143-148.

Ravindra, M. R. and T.K. Goswami, 2007. Post-harvest handling and storage of mangos an overview. Journal of Food Science and Technology. 44 (5): 449-458.

Serrano, M., S. Castillo, J. Valverde, D. Martianez-Romero, F. Guillean and D. Valero, 2006. Use of Aloe Vera gel coating preserves the functional properties of table grapes. Agricultural and Food Chemistry, 54: 3882-3886.

Shi, S., W. Wang, L. Liu, S. Wu, Y. Wei and W. Li, 2013. Effect of chitosan/nano-silica coating on the physicochemical characteristics of longan fruit under ambient temperature. Journal of Food Engineering, 118 (1), 125-131.

Shibuya, N. and E. Minami, 2001. Oligosaccharide signaling for defence responses in plant. Physiol. Mol. Plant Pathol, 59, 223-233.

Shigemasa, Y., K. Saito, H. Sashiwa and H. Saimoto, 1994. Enzymatic degradation of chitins and partially deacetylated chitins. Int. J. Biol. Macromol., 16(1): 43-49.

Srinivasa, P., R. Baskaran, M. Ramesh, K.H. Prashanth and R. Tharanathan, 2002. Storage studies of mango packed using biodegradable chitosan film. Eur. Food Res. Technol., 215(6): 504-508.

Tripathi, P. and N. K. Dubey, 2004. Exploitation of natural products as an alternative strategy to control postharvest fungal rotting of fruit and vegetables. Postharvest Biology and Technology. 32(3): 235-245.

Wang, J., B. Wang, W. Jiang and Y. Zhao, 2007. Quality and shelf life of mango (Mangifera indica, L. cv. "Tainong") coated by using chitosan and polyphenols. Food Sci. Technol. Int., 13, 317322.

Wang, L., H. Wu, G. Qin and X. Meng, 2014. Chitosan disrupts Penicillium expansum and controls postharvest blue mold of jujube fruit. Food Control, 41, 56-62.

Wills, R.B.H., P.A. Bembridge and K.J. Scott, 1980. Use of flesh firmness and other objective tests to determine consumer acceptability of Delicious apples. Aust. J. Exp. Agri. and Ainm., 20: 252256.

Wongmetha, O. and L.S. Ke, 2012. The quality maintenance and extending storage life of mango fruit after postharvest treatments. World Academy of Science, Engineering and Technology, 69: 936-941.

Yu, Y., S. Zhang, Y. Ren, H. Li, X. Zhang and J. Di, 2012. Jujube preservation using chitosan film with nano-silicon dioxide. Journal of Food Engineering, 113, 408-414.

Zeng, K., Y. Deng, J. Ming and L. Deng, 2010. Induction of disease resistance and ROS metabolism in navel oranges by chitosan. Scientia Horticulturae, 126, 223-228.

Zheng, X., L. Ye, T. Jiang, G. Jing, and J. Li, 2012. Limiting the deterioration of mango fruit during storage at room temperature by oxalate treatment. Food Chemistry. 130(2): 279-285.

Zhong, Q.P. and W.S. Xia, 2007. Effect of 1-methylcyclopropene and/or chitosan coating treatments on storage life and quality maintenance of Indian jujube fruit. LWT-Food Sci. Technol., 40(3): 404- 411.

Zhu, X., Q.M. Wang, J.K. Cao and W.B. Jiang, 2008. Effects of chitosan coating on postharvest quality of mango (Mangifera indica L. CV. Tainong) fruits. J. Food Process. Preserv., 32, 770784. 